\title{
Citral accumulation in Cymbopogon citratus plant as influenced by N6-benzylaminopurine and light intensity
}

\author{
Claudia Lopes Prins ${ }^{1 *}$, Silvério de Paiva Freitas ${ }^{1}$, Mara de Menezes de Assis \\ Gomes $^{2}$, Ivo José Curcino Vieira ${ }^{3}$, Geraldo de Amaral Gravina ${ }^{4}$
}

'Weeds and Medicinal Plants, Plant Production Laboratory, Centro de Ciências e Tecnologias Agropecuárias, Universidade

Estadual do Norte Fluminense Darcy Ribeiro (CCTA/UENF), Campos dos Goytacazes, RJ, Brazil.

${ }^{2}$ Plant Physiology Laboratory, CCTA/UENF, Campos dos Goytacazes, RJ, Brazil.

${ }^{3}$ Natural Products Laboratory, CCT/UENF, Campos dos Goytacazes, RJ, Brazil.

${ }^{4}$ Statistics, Agricultural Engineering Laboratory, CCTA/UENF, Campos dos Goytacazes, RJ, Brazil.

*Corresponding author: prins@uenf.br

Received: 19 September 2012; Accepted: 15 July 2013

ABSTRACT: Cymbopogon citratus (lemongrass) is an aromatic species whose essential oil is rich in citral, with industrial applications due to its lemon scent. The effects of environmental factors on the percentage and composition of essential oils are the main challenges in commercial cultivation. Various studies have indicated the positive effect of cytokinin on terpene production. The present work aimed to evaluate the effect of N6-benzylaminopurine (BAP) associated with light intensity on the production and composition of essential lemongrass oil. Plants were grown under field conditions (FIELD) and shade (SHADE). The study employed a 2x7 factorial scheme with two growing environments, seven BAP concentrations, and five replicates. After seven months of growth, a single application of the synthetic cytokinin BAP was performed at concentrations $0,30,60,90,120,150$, and $180 \mathrm{mg} \mathrm{L}^{-1}$. One week after the BAP application, plants were harvested and the essential oil was extracted in a Clevenger apparatus. The chemical composition of the essential oil of plants treated with 60,120 , and $180 \mathrm{mg} \mathrm{L}^{-1}$ of BAP was determined by Gas Chromatography (GC). The essential oil percentage was not affected by the treatments, showing $1.08 \%$ on average. On the other hand, the citral percentage was negatively influenced by BAP, and light intensity had no effects. In plants treated with $60 \mathrm{mg} \mathrm{L}^{-1}$ of BAP, citral percentage was $72 \%$, on average, while in plants treated with $180 \mathrm{mg} \mathrm{L}^{-1}$, the mean percentage of citral was $33 \%$.

KEYWORDS: cytokinin, essential oil, lemongrass, shade.

Physiological and biochemical changes that occur during plant ontogeny regulate, in a programmed way, gene expression, as well as the activity of enzymes involved in secondary metabolism pathways. This genetic program can be influenced by exogenous factors which alter the physiological status, induce biochemical changes, and/or are signals triggering a set of responses that will culminate in the biosynthesis of the secondary metabolites.

Terpenoids are a class of secondary metabolites composed of isopentenyl diphosphate (IPP), a $\mathrm{C}_{5}$ carbon compound resulting from the combination between methylerythritol phosphate and glyceraldehyde 3-P (Rodriguez-Concepción 2006, Cheng et al. 2007). IPP is the precursor of most monoterpenes as they are formed by the combination with an isoprene molecule. Essential oils are formed mainly by monoterpenes, and are lipophilic and aromatic substances produced by a range of aromatic plant species, widely used for their scent and flavor. Cymbopogon citratus (lemongrass) is an aromatic species whose essential oil is rich in citral and is valued in many industries for the lemon scent (Budavani et al. 1996). C. citratus, the West-Indian lemongrass, is the species grown in 
Brazil. The Southern region of Brazil commercially produces this cultivar, but the low temperatures that occur in this area hinder its production to some extent (Gomes et al. 2004). This species is characterized by perennial growth and rusticity, conferring resistance to drought when compared to C. flexuosus, the East-Indian lemongrass, which is the one cultivated in Asia.

Discovered in the 1950's, cytokinins are associated with cell proliferation processes. They are also involved in senescence delay, pigment synthesis, chloroplast production (Chernyad'ev 2000), cellular differentiation (Ioio et al. 2007), regulation of gene expression, and indirectly influence the synthesis of compounds such as jasmonate and salicylic acid (Sano et al. 1996). Cytokinin takes part in light response modulation and affects the circadian rhythm regulation and phytochrome functions (Chen et al. 2006, Naito et al. 2007, Yakir et al. 2007).

Environmental conditions can influence essential oil biosynthesis, since it may alter hormonal balance. Thus, phytohormones may act as signals that can, directly or indirectly, induce secondary metabolites biosynthesis (Prins et al. 2010). Light availability and quality can be positively associated with essential oil production, as observed with Cymbopogon flexuosus, which showed an increase of approximately $30 \%$ in essential oil biosynthesis when plants were treated with red light (Sangwan et al. 2001). The influence of light on essential oil production can occur due to the increased biomass, as observed in Baccharis trimera (Silva et al. 2006), Aloysia gratissima (Pinto et al. 2007), and Mentha piperita (Maffei et al. 1999).

The enhancement of essential oil production through plant growth regulator applications can be verified in vitro and in vivo. Various experiments indicate the positive effects of cytokinin on terpene production (El-Keltawiand Croteau 1987, Decenditetal. 1993, Stoeva and Iliev 1997, Khandelwal et al. 2002, Sudriá et al. 2004, Papon et al. 2005, Shah 2007). Nevertheless, responses vary according to the species, the developmental stage, and other factors, such as concentration and environmental conditions that influence the action of growth regulators (Sanches 2000). The effect of cytokinin on essential oil production can be associated with an increase in photosynthetic activity, as a consequence of the higher number of chloroplasts or enhanced chlorophyll biosynthesis, biomass production, increased secretory storage formation and senescence delay (since leaves are sites of essential oil biosynthesis), and interaction with exogenous signals such as light (Prins et al. 2010).

Although plants with high levels of cytokinin show normal growth in the dark, it is known that processes regulated by light can be triggered when high quantities of cytokinin are applied (Kraepiel and Miginiac 1997). Taking into account the positive effects of light on the essential oil production, favored by dry mass production or by the precursor's synthesis and the relationship of cytokinin to light, the present work aimed to evaluate the effects of light and cytokinin application on the essential oil production and the chemical composition of lemongrass plants grown in open-field and shade conditions.

Lemongrass (Cymbopogon citratus, a voucher herbarium specimen is deposited with the number $n^{\circ} 436381$, Rio de Janeiro Botanical Garden) seedlings obtained through vegetative propagation were grown in $42 \mathrm{~L}$ pots (one plant per pot) filled with soil, sand, and manure $(1: 1: 1, \mathrm{v} / \mathrm{v} / \mathrm{v})$. These seedlings were grown in $1 \times 1 \mathrm{~m}$ spaces and kept from planting to harvest under two distinct light conditions, i.e. SHADE, where plants were grown in a screen-house ( $30 \%$ shade), over which a black screen ( $50 \%$ shade) was positioned to reduce light incidence, and FIELD, where pots were kept in an open field.

A randomized block design was employed in a $2 \times 7$ factorial scheme, with two light intensities (SHADE $-183 \mu \mathrm{mol} \mathrm{m}^{-2} \mathrm{~s}^{-1}$ on average, and FIELD - $1210 \mu \mathrm{mol} \mathrm{m}{ }^{-2} \mathrm{~s}^{-1}$ on average), and seven N6-benzylaminopurine concentrations, with five repetitions.

A solution of N6-benzylaminopurine (Microbiológica ${ }^{\circledR}$ ) was applied seven months after planting in the following concentrations: $0,30,60,90,120,150$, and $180 \mathrm{mg} \mathrm{L}^{-1}$. BAP was initially diluted with $\mathrm{NaOH}(1 \mathrm{M})$, and after the preparation of the solution, $\mathrm{pH}$ was adjusted with $\mathrm{HCl}$. The BAP solution $(50 \mathrm{~mL}$ containing Tween 80 as surfactant agent) was sprayed (handy sprayer Ultrajet 500, Guarany ${ }^{\circ}$ ) on each plant. This volume was previously tested in order to maintain shoots completely wet.

A week after the BAP treatment, plants were harvested. Shoots were divided into leaves and tillers, and fresh weight was determined. Afterwards, the plant material was submitted to drying $\left(40^{\circ} \mathrm{C}\right)$ in order to determine the dry weight of leaves and tillers. Dried leaves were used for essential oil extraction by hydrodistillation in a Clevenger apparatus (MA553/2000, Marconi, São Paulo, Brazil) for a period of 2 hours.

To evaluate the effect of BAP on chemical composition, essential oil from plants treated with 60,120 , and $180 \mathrm{mg}$ $\mathrm{L}^{-1}$ of BAP were submitted to chemical analysis using Gas Chromatography (A-17, Shimadzu, Kyoto, Japan) and the citral concentration was determined by the external calibration with citral standard (Sigma-Aldrich ${ }^{\odot}$ ). Analyses were carried out for the following conditions: $30 \mathrm{~m}$ long DB5 capillary column, with $0.25 \mathrm{~mm}$ inner diameter, injector temperature of $200^{\circ} \mathrm{C}$, column temperature of $50^{\circ} \mathrm{C}$ to $230^{\circ} \mathrm{C}, 15^{\circ} \mathrm{C} \mathrm{min}{ }^{-1}$, pressure of $87.5 \mathrm{KPa}$ to $171 \mathrm{KPa}, 7 \mathrm{KPa}$ $\mathrm{min}^{-1}$, detector temperature $230^{\circ} \mathrm{C}$, split ratio $1: 20$, and solvent cut $3 \mathrm{~min}$. The essential oil was diluted in hexane and a final concentration of $25 \mu \mathrm{L} \mathrm{mL}{ }^{-1}$ was obtained. The injection volume was $1 \mu \mathrm{L}$. Citral percentage was obtained by an external calibration curve using citral standard (SigmaAldrich $^{\odot}$ ) in the concentrations 10, 15, 20, 25, 30, 50, and 100 
$\mu \mathrm{L} \mathrm{mL}{ }^{-1}$. The peak area of known concentrations was used to obtain the citral concentration of the samples.

As the BAP treatment showed an effect on citral percentage, total protein concentration was determined. Within the same growth conditions, third and fourth lemongrass leaves were collected and used for protein extraction according to Natarajan et al. (2005). The plant material was frozen in liquid nitrogen and ground into a fine powder, and the extraction buffer used was thiourea/urea. Protein concentration was determined using the 2D-Quati Kit (GE-Healthcare ${ }^{\circledR}$ ), with bovine serum albumin (BSA) as standard.

Under FIELD treatment, plants produced a high amount of tiller and leaf biomass (Table 1). The percentage of essential oil was not influenced by BAP concentrations or light intensity. The average percentage of essential oil was $1.08 \%$ (Table 2), but the content of essential oil (g per plant) was higher in plants grown under FIELD conditions. This demonstrates a favorable effect of light for essential oil production through the effect on biomass.

In the tested experimental conditions, lemongrass essential oil production was not affected by shade. This indicates that the species is able to maintain its production under reduced light availability. However, citral (neral+geranial) percentage was negatively influenced by BAP. An inverse correlation was observed between BAP and citral (Figure 1), i.e. higher concentrations of $\mathrm{BAP}$ reduced the citral percentage in lemongrass essential oil.

Total protein concentration was determined and an increased response to BAP was observed (Figure 2). No differences were observed in relation to growth environment (FIELD or SHADE). However, the results indicated that the higher the BAP concentration, the higher the total protein concentration.

The regulation of essential oil biosynthesis is complex and depends on a wide range of factors. Genetic control and its interaction with the environment are decisive in essential oil production, as this class of metabolites is associated with the plant's response to its surroundings (Sangwan et al. 2001, Gershenzon 1994). In this work, C. citratus plants growing under shade conditions were less developed when compared to control plants, and, consequently, their biomass (leaves and tillers) was reduced, which also resulted in a reduced yield of essential oil. However, the essential oil content was not affected by the treatments. Although stressful conditions are commonly associated with alterations in secondary metabolite biosynthesis, this is not always the case, since responses to environmental changes are different according to the species, stage of growth, and stress factors. As it was observed in lemongrass, Ocimum selloi did not present increased essential oil content (estragole and anethole) when submitted to partial shading (Gonçalves et al. 2003). In Aloysia gratissima plants, the essential oil yield in plants grown under full sunlight $\left(0.73\right.$ g plant $\left.^{-1}\right)$ and $40 \%$ shading (0.88 g plant $\left.^{-1}\right)$ was significantly higher than in those grown at $80 \%$ shading (0.26 g plant $^{-1}$ ) (Pinto et al. 2007). In Hyptis marrubioides, the content of essential oil was not influenced by the levels of irradiation (20, 60 and $100 \%$ of natural light), but the essential oil yield was higher when plants were grown at the level of $100 \%$ irradiation (Sales et al. 2009). This result is in agreement with our data, i.e. severe shading led to a decrease in essential oil yield due to the reduced biomass yield.

Itisknown that thehigh production of photoassimilates under adequate light availability can contribute to improve essential oil biosynthesis through increased IPP and DMAPP (dimethylallyl pyrophosphate) availability (Peer and Langenheim 1998,

Table 2. Effect of FIELD, SHADE, and BAP treatments on lemongrass essential oil (\%)

\begin{tabular}{|c|c|c|c|}
\hline \multirow{3}{*}{$\begin{array}{c}\text { BAP } \\
\text { concentration } \\
\left(\mathrm{mg} \mathrm{L}^{-1}\right)\end{array}$} & \multicolumn{2}{|c|}{ Lemongrass essential oil (\%) } & \multirow{3}{*}{ Average } \\
\hline & \multicolumn{2}{|c|}{ Light intensity } & \\
\hline & FIELD & SHADE & \\
\hline 0 & 1.10 & 1.38 & 1.24 \\
\hline 30 & 1.15 & 0.90 & 1.03 \\
\hline 60 & 0.92 & 1.18 & 1.05 \\
\hline 90 & 1.10 & 0.81 & 0.96 \\
\hline 120 & 0.88 & 1.06 & 0.97 \\
\hline 150 & 1.13 & 1.46 & 1.30 \\
\hline 180 & 1.12 & 0.92 & 1.02 \\
\hline Average & $1.06^{\mathrm{A}}$ & $1.10^{\mathrm{A}}$ & \\
\hline \multicolumn{4}{|c|}{ Total Average $1.08 \%$} \\
\hline & \multicolumn{2}{|c|}{ Essential oil yield (g plant ${ }^{-1}$ ) } & \\
\hline & FIELD & SHADE & \\
\hline & $2.40^{\mathrm{A}}$ & $0.84^{\mathrm{B}}$ & \\
\hline
\end{tabular}

Values followed by the same letters are not significantly different at 0.05 level by the Tukey's test.

Table 1. Effect of FIELD, SHADE, and BAP treatments on total fresh weight (TFW), leaves fresh weight (LFW), tillers fresh weight (TilFW), total dry weight (TDW), leaves dry weight (LDW), and tillers dry weight (TilDW) of lemongrass

\begin{tabular}{|c|c|c|c|c|c|c|}
\hline \multirow{2}{*}{ Treatments } & TFW & LFW & TilFW & TDW & LDW & TilDW \\
\hline & \multicolumn{6}{|c|}{$\left(\right.$ g plant $\left.^{-1}\right)$} \\
\hline FIELD & $1566.91^{A}$ & $683.91^{A}$ & $883.00^{A}$ & $437.65^{A}$ & $221.19^{A}$ & $216.46^{A}$ \\
\hline SHADE & $517.19^{\mathrm{B}}$ & $264.22^{\mathrm{B}}$ & $252.97^{B}$ & $118.15^{\mathrm{B}}$ & $78.06^{\mathrm{B}}$ & $40.09^{B}$ \\
\hline
\end{tabular}

Values followed by the same letters are not significantly different at 0.05 level by the Tukey's test. 


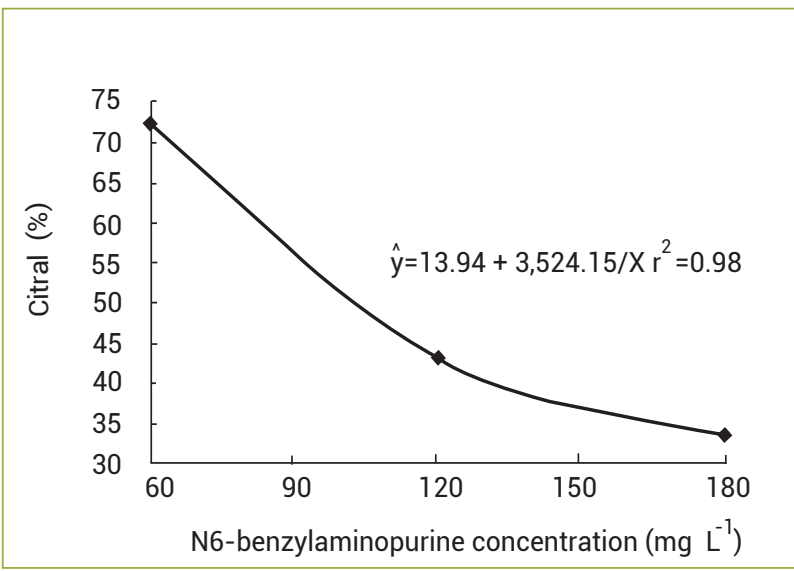

Figure 1. Percentage of citral in the essential oil of lemongrass treated with $N 6$-benzylaminopurine $\left(60,120\right.$ and $\left.180 \mathrm{mg} \mathrm{L}^{-1}\right)$

Rodriguez-Concepción 2006). The increased availability of these compounds might lead to an increment on essential oil content, since both IPP and DMAPP are terpenoid precursors. However, in the present work, no direct effect of light levels was verified on essential oil content. On the other hand, our results indicate the influence of BAP on essential oil composition, and this effect could be related to IPP and DMAPP availability.

When exogenous cytokinin application and essential oil production were correlated, it was verified that increasing BAP concentrations caused the reduction on citral percentage. Thus, cytokinin probably has an inhibitory effect on citral production. A similar relationship was observed by Gharib (2005) in tissue cultures of Pelargonium nervosum. The author verified that cytokinin induced cell differentiation and that this factor was responsible for quantitative and qualitative alterations in essential oil (Gharib 2005). According to this author, a reduction in BAP concentration led to an increased citral percentage.

This effect, which resulted in the reduction of citral percentages caused by BAP, could be associated with a general effect on cytokinin as a growth and metabolic enhancer. It is well known that cytokinin promotes growth and related pathways could be activated, and thus leading more precursors to be required. IPP and DMAPP are precursors of a range of compounds such as terpenoids.

Citral is a mixture of two geometric isomers, neral and geranial. These isomers originated from geraniol diphosphate (GPP), the first metabolite formed in the essential oil biosynthesis pathway. To form GPP, an IPP and a DMAPP are bond giving origin to a $\mathrm{C}_{10}$ compound, or a monoterpene (Rodriguez-Concepción 2006). DMAPP is also present during the cytokinin biosynthesis (KamadaNobusada and Sakakibara 2009). Taking into account that IPP and DMAPP are precursors of a wide range of primary

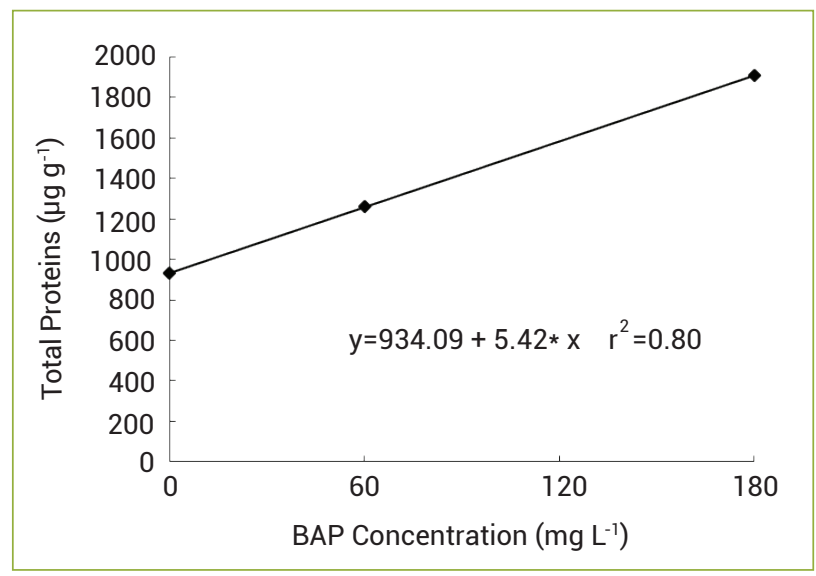

Figure 2. Effect of BAP on total protein $\left(\mu \mathrm{g} \mathrm{g}^{-1}\right)$ concentration.

and secondary metabolites, the results obtained in the present work may indicate that the BAP application stimulates the metabolism of terpenoid precursors in lemongrass, reducing their availability for citral biosynthesis.

The relationship between precursor availability and terpenoid biosynthesis was reported by Aharoni et al. (2003), who verified reduced growth in Arabidopsis plants genetically modified to overproduce mono and sesquiterpenes. Their results indicated that precursors could be used for terpenoid biosynthesis or plant development. Masferrer et al. (2002) evaluated cytokinin levels on Arabidopsis overexpressing farnesyl diphosphate synthase, an enzyme present on the sesquiterpenes pathway, and observed a reduction of endogenous cytokinin levels in transformed plants. These authors demonstrated that the low level of cytokinins was due to the alteration of IPP and DMAPP partitioning, being these compounds redirected to farnesyl diphosphate biosynthesis. This indicates a close relationship between IPP and DMAPP availability, growth and terpenoids biosynthesis, in which those compounds would be allocated to the more active pathway.

The application of different concentrations of indole-3acetic acid (IAA), benzyladenine (BA), zeatin (ZEA) and kinetin (KIN) at $1.0 \mu \mathrm{M}$ on tissue culture of Thymus vulgaris caused a decrease in p-cymene production, while the highest concentration of BA and ZEA increased its proportion (Affonso et al. 2009). Thus, the type of cytokinin applied can also modify the responses on the quality and quantity of the essential oil.

According to Manzano et al. (2006), HMG-CoA (3-hydroxy-methyl-glutaryl coenzyme-Areductase) is the main regulatory enzyme in IPP and DMAPP biosynthesis, and the partitioning of these compounds is finely regulated to prevent its shortage during the synthesis of other isoprenoid compounds. Such regulation can be shown by experimental data, in which unbalanced activities of enzymes that supply or compete 
for these substrates limit the synthesis of some isoprenoids (Masferrer et al. 2002). Sudriá et al. (1999) observed that in Lavandula dentata, HMG-CoA activity was $140 \%$ higher in plants treated with cytokinin. According to these authors, the increased activity of this enzyme may be due to enhanced plant metabolism. So, the increased cytokinin levels, through exogenous application, may also have an important role to regulate isoprenoid precursors by its effect on enzyme activity or synthesis.

Our data suggest that cytokinin led to enhanced plant metabolism by increasing total protein concentration. It has been shown that the exogenous application of cytokinins influences mRNA populations or the level of specific mRNAs of unknown function (Roitsch and Ehneß 2000). The increase in crude proteins in Andropogon gerardi, a grass species, was also observed when $\mathrm{BA}\left(5,10,20\right.$ and $\left.40 \mathrm{mg} \mathrm{L}^{-1}\right)$ was applied, but its effects were dependent on the period of year, and it was verified that some dosages were more efficient than others (Towne and Owensby 1983). It was demonstrated that exogenous application of zeatin riboside (ZR) in Agrostis stolonifera L., another grass species, alleviated heat stress injury, probably by slowing down the action of protease and by upregulating heatshock proteins. The higher content of total protein in Agrostis stolonifera was attributed to a reduction in protein degradation due to cytokinin treatment (Veerasamy et al. 2007).

Recently, Žd'arská et al. (2013) observed that BAP mediated the regulation of proteins involved in RNA transport, and initiation of translation, or protein degradation, revealed potential BAP targets for this type of regulation. These authors showed that BAP predominantly regulates proteins involved in carbohydrate and energy metabolism in the shoot, as well as protein synthesis and destination in the root.

\section{REFERENCES}

Affonso VR, Bizzo HR, Lage CLS, Sato A (2009) Influence of growth regulators in biomass production and volatile profile of in vitro plantlets of Thymus vulgaris. Journal of Agricultural and Food Chemistry 57:6392-6395.

Aharoni A, Giri AP, Deuerlein S, Griepink F, Kogel WJ, Verstappen FWA, Verhoeven HA, Jongsman MA, Schwab W, Bouwmeester HJ (2003) Terpenoid metabolism in wild-type and transgenic Arabidopsis plant. The Plant Cell 15:2866-2884.

Alizadeh O, Haghighi BJ, Ordookhani K (2010) The effect of exogenous cytokinin application on sink size in bread wheat (Triticum aestivum). African Journal of Agricultural Research 5:2893-2898.

Budavani S, O'Neil MJ, Smith A, Heckelman PE, Kinneary JF (ed.) (1996) The Merck Index - an encyclopedia of chemicals, drugs, and biologicals. Merck Research Laboratories, New Jersey, USA.
In the present work, the effects of light intensity and exogenous cytokinin on lemongrass growth and essential oil production and quality were evaluated. The growing parameters were unaltered in relation to BAP application, but plants grown under light conditions were greater than those grown under shade conditions. It was observed that there was no effect of light intensity on essential oil content, while essential oil yield was higher in plants grown at full light as a result of increased biomass. Thus, it can be concluded that this species was not directly influenced by light as promoting essential oil production, since no differences between light and shade treatments were observed. Regarding quality, expressed by citral percentage, the effect of light intensity was not observed. However, BAP application had a negative effect on citral percentage and a positive relationship with total protein concentration. Our results showed that the reduction on citral percentage could be associated to BAP effects on plant metabolism. Although we cannot demonstrate it, total protein concentration increased, which could indicate high metabolic activity and, consequently, an increase on IPP and DMAPP precursors for primary metabolites biosynthesis to the detriment of citral synthesis.

\section{ACKNOWLEDGMENTS}

The authors would like to thank CAPES and FAPERJ for the financial support, which helped make this study possible. In addition, they would like to extend gratitude to Microbiológica ${ }^{\circledR}$ and Jaime Rabi for supplying N6-benzylaminopurine and to Prof. Dr. Vanildo Silveira (Biotechnology Laboratory, CBB/UENF) and to his students Angelo Heringer and Ricardo Reis for protein analysis support.

Chen D, Li Z, Pan R, Wang X (2006) Anthocyanin accumulation mediated by blue light and cytokinin in Arabidopsis seedlings. Journal of Integrative Plant Biology 48:420-425.

Cheng AX, Lou YG, Mao YB, Lu S, Wang LJ, Chen XY (2007) Plant terpenoids: biosynthesis and ecological functions. Journal of Integrative Plant Biology 49:179-186.

Chernyadev II (2000) Ontogenetic changes in the photosynthetic apparatus and effects of cytokinins. Applied Biochemistry and Microbiology 36:527-539.

Decendit A, Petit G, Andreu F, Doireau P, Mérillon JM, Rideau M (1993) Putative sites of cytokinin action during their enhancing effect on indole alkaloid accumulation in periwinkle cell suspensions. Plant Cell Reports 12: 710-712.

El-Keltawi NE, Croteau R (1987) Influence of foliar applied cytokinins on growth and essential oil content of several members of the Lamiaceae. Phytochemistry 26:891-895. 
Gershenzon J (1994) Metabolic costs of terpenoid accumulation in higher plants. Journal of Chemical Ecology 20: 1281-1328.

Gharib FAE (2005) Changes in regeneration and oil accumulation of Pelargonium nervosum under various culture conditions. Journal of Biological Sciences 5:670-677.

Gomes EC, Rücker NGA, Negrelle RRB (2004) Estudo prospectivo da cadeia produtiva do capim-limão - Estado do Paraná. Revista de Economia e Sociologia Rural 42:709-731.

Gonçalves LA, Barbosa LCA, Azevedo AA, Casali VWD, Nascimento EA (2003) Production and composition of essential oil of "Alfavaquinha" (Ocimum selloi Benth) to two levels of solar radiation. Revista Brasileira de Plantas Medicinais 6:8-14.

Ioio RD, Linhares FS, Sabatini S (2007) Emerging role of cytokinin as a regulator of cellular differentiation. Current Opinion in Plant Biology 110:1-5.

Kamada-Nobusada T, Sakakibara H (2009) Molecular basis for cytokinin. Phytochemistry 70:444-449.

Khandelwal SK, Gupta NK, Sahu MP (2002) Effect of plant growth regulators on growth, yield and essential oil production of henna (Lawsonia inermis L.). Journal of Horticultural Science and Biotechnology 77:67-72.

Kraepiel Y, Miginiac E (1997) Photomorphogenesis and phytohormones. Plant, Cell \& Environment 20:807-812.

Maffei M, Canova D, Bertea CM, Scannerini S (1999) UV-A effects on photomorphogenesis and essential oil composition in Mentha piperita. Journal of Photochemistry and Photobiology 52:105-110.

Manzano D, Busquets A, Closa M, Hoyerová K, Schaller H, Kamínek M, Arró M, Ferrer A (2006) Overexpression of farnesyl diphosphate synthase in Arabidopsis mitochondria tiggers light-dependent lesion formation and alters cytokinin homeostasis. Plant Molecular Biology 61:195-213.

Masferrer A, Arró M, Manzano D, Schaller H, FernándezBusquets $X$, Moncaleán $P$, Fernández $B$, Cunillera N, Boronat A, Ferrer A (2002) Overexpression of Arabidopsis thaliana farnesyl diphosphate synthase (FPS1S) in transgenic Arabidopsis induces a cell death/senescence-like response and reduced cytokinin levels. The Plant Journal 30:123-132.

Naito T, Kiba T, Koizumi N, Yamashino T, Mizuno T (2007) Characterization of a unique GATA family gene that responds to both light and cytokinin in Arabidopsis thaliana. Bioscience, Biotechnology, and Biochemistry 71:1557-1560.

Natarajan S, Xu C, Caperna TJ, Garrett WM (2005) Comparison of protein solubilization methods suitable for proteomic analysis of soybean seed proteins. Analytical Biochemistry 342:214-220.

Papon N, Bremer J, Vansiri A, Andreu F, Rideau M, Crèche $J$ (2005) Cytokinin and ethylene control indole alkaloid production at the level of the MEP/Terpenoid pathway in Catharanthus roseus suspension cells. Planta Medica 71:572-574.

Peer WA, Langenheim JH (1998) Influence of phytochrome on leaf monoterpene variation in Satureja douglasii. Biochemical Systematics and Ecology 26:25-34.
Pinto JEBP, Cardoso JCW, Castro EM, Bertolucci SK, Melo LA, Dousseau S (2007) Morphophysiological aspects and essential oil content in Brazilian-lavender as affected by shadowing. Horticultura Brasileira 25:210-214.

Prins CL, Vieira IJC, Freitas SP (2010) Growth regulators and essential oil production. Brazilian Journal of Plant Physiology 22:91-102

Rodríguez-Concepción M (2006) Early steps in isoprenoid biosynthesis: multilevel regulation of the supply of common precursors in plant cells. Phytochemistry Reviews 5:1-15.

Roitsch T, Ehneß R (2000) Regulation of source/sink relations by cytokinins. Plant Growth Regulation 32:359-367.

Sales JF, Pinto JEBP, Ferri PH, Silva FG, Oliveira CBA, Botrel PP (2009) Influência do nível de irradiância no crescimento, produção e composição química do óleo essencial de hortelã do campo (Hyptis marrubioides Epl.). Semina - Ciências Agrárias 30:389-396.

Sanches RR (2000) Aplicação de biorreguladores vegetais: aspectos fisiológicos e aplicações práticas na citricultura mundial. Funep, Jaboticabal. 160p.

Sangwan NS, Farooqi AHA, Shabih F, Sangwan RS (2001) Regulation of essential oil production in plants. Plant Growth Regulation 34:3-21.

Sano H, Seo S, Koizumi N, Niki T, Iwamura H, Ohashi Y (1996) Regulation by citokinins of endogenous levels of jasmonic acid and salicylic acids in mechanically wounded tobacco plants. Plant and Cell Physiology 37:762-769.

Shah SH (2007) Effect of kinetin spray on growth and productivity of Black cumin Plants. Russian Journal of Plant Physiology 54:702-705.

Silva FG, Pinto JEBP, Cardoso MG, Nascimento EA, Nelson DL, Sales JF, Mol DJS (2006) Influence of radiation level on plant growth, yield and quality of essential oil in carqueja. Ciência e Agrotecnologia 30: 52-57.

Sokolova SV, Balakshina NO, Krasavina MS (2002) Activation of soluble acid invertase accompanies the cytokinininduced source-sink leaf transition. Russian Journal of Plant Physiology 49:86-91.

Stoeva T, lliev L (1997) Influence of some phenylureia cytokinins on spearmint essential oil composition. Bulgarian Journal of Plant Physiology 23:66-71.

Sudriá C, Piñol MT, Palazón J, Cusidó RM, Vila R, Morales C, Bonfill M, Cañigueral S (1999) Influence of plant growth regulators on the growth and essential oil content of cultured Lavandula dentata plantlets. Plant Cell, Tissue and Organ Culture 58:177-184.

Sudriá C, Palazón J, Cusidó R, Bonfill M, Piñol MT, Morales C (2004) Effect of benzyladenine and indolebutyric acid on ultrastructure, glands formation, and essential oil accumulation in Lavandula dentata plantlets. Physiologia Plantarum 44:1-6. 
Towne G, Owensby C (1983) Cytokinins effect on protein and chlorophyll content of big bluestem leaves. Journal of Range Management Archives 36:75-77.

Veerasamy M, He Y, Huang B (2007) Leaf senescence and protein metabolism in creeping bentgrass exposed to heat stress and treated with cytokinins. Journal of the American Society for Horticultural Science 132:467-472.
Yakir E, Hilman D, Harir Y, Green RM (2007) Regulation of output from the plant circadian clock. FEBS Journal 274:335-345.

Žd'arská M, Zatloukalová P, Benítez M, Šedo O, Potěšil D, Novák O, Svačinová J, Pešek B, Malbeck J, Vašíčková J, Zdráhal Z, Hejátko $J$ (2013) Proteome analysis in Arabidopsis reveals shoot- and root-specific targets of cytokinin action and differential regulation of hormonal homeostasis. Plant Physiology 161:918-930. 